Review

\title{
Curcumin and Osteosarcoma: Can Invertible Polymeric Micelles Help?
}

\author{
Avudaiappan Maran ${ }^{1}$, Michael J. Yaszemski ${ }^{1}$, Ananiy Kohut ${ }^{2}$ and Andriy Voronov ${ }^{3, *}$ \\ 1 Department of Orthopedics, Mayo Clinic, 200 1st St SW, Rochester, MN 55905, USA; \\ maran.avudai@mayo.edu (A.M.); yaszemski.michael@mayo.edu (M.J.Y.) \\ 2 Department of Organic Chemistry, Lviv Polytechnic National University, vul. S. Bandery, 12, Lviv 79013, \\ Ukraine; ananiy.kohut@gmail.com \\ 3 Department of Coatings and Polymeric Materials, North Dakota State University, NDSU Dept. 2760, \\ P.O. Box 6050, Fargo, ND 58108-6050, USA \\ * Correspondence: andriy.voronov@ndsu.edu; Tel.: +1-701-231-9563
}

Academic Editor: Carlos Lodeiro

Received: 17 May 2016; Accepted: 23 June 2016; Published: 27 June 2016

\begin{abstract}
Systematic review of experimental and clinical data on the use of curcumin in the treatment of osteosarcoma is presented. The current status of curcumin's therapeutic potential against bone cancer is analyzed in regard to using polymeric micelles (including recently developed invertible, responsive, micelles) as a platform for curcumin delivery to treat osteosarcoma. The potential of micellar assemblies from responsive macromolecules in a controlled delivery of curcumin to osteosarcoma cells, and the release using a new inversion mechanism is revealed.
\end{abstract}

Keywords: invertible polymer micelles; micellar nanoassemblies; curcumin delivery; bone tumor treatment

\section{Introduction}

Osteosarcoma is a common primary type of malignant bone tumor in children and young adults. As a very aggressive tumor, associated with poor prognosis, it is currently the sixth leading cancer in children under 15 years of age [1]. A second peak in the incidence of osteosarcoma occurs in the elderly, and is usually associated with underlying bone pathology, such as Paget's disease, medullary infarct, or prior irradiation [2,3]. For children and young adults, osteosarcoma most frequently occurs in developing bones, and often results in metastases in the lungs and subsequent failure of the respiratory system [4,5]. Eventually, about $30 \%$ of patients with an osteosarcoma diagnosis develop lung metastases, which explains the fact that the overall prognosis is poor $[2,6,7]$. Current strategies for osteosarcoma treatment consist of radiation therapy and surgery, including adjuvant chemotherapy with various antitumor agents at high doses [2]. The standard clinical treatment consists of presurgical (neoadjuvant) chemotherapy, followed by surgical resection of the primary tumor after the second or third cycle of the year-long chemotherapy regimen. For the treatment of osteosarcoma, cisplatin, doxorubicin, adriamycin, methotrexate, ifosfamide, and etoposide are the most commonly used drugs $[8,9]$.

However, the five-year survival rate for patients with metastatic osteosarcoma is still very low $(20 \%)$ [2]. In addition, use of these drugs promotes toxicity and side effects in this aggressive cancer, as well as frequently causing chemoresistance $[3,10-13]$.

\subsection{Curcumin and Its Molecular Targets}

Present in the spice turmeric, curcumin is derived from the rhizome of Curcuma longa and has been traditionally applied for the treatment of various diseases in Chinese and Indian medicine. 
This phytochemical has recently attracted the attention of clinicians as a powerful antioxidant with strong anti-inflammatory properties [14,15], and as a potential agent for anticancer therapy [16-19]. Although the bioavailability of curcumin is low, it provides a variety of beneficial effects in living organisms, including proliferation inhibition and an antitumor effect in various cancer cells [20,21]. There are many ongoing clinical trials worldwide that seek to understand the molecular mechanisms for curcumin activity in cells, as well as the biological effects of curcumin in both cell and animal model systems [22]. Although there are studies indicating that curcumin can be cytotoxic for normal cells [23-27], it has in general been shown that cancer cells are much more sensitive to curcumin than their normal counterparts [28]. Curcumin has not shown any adverse side effects in clinical trials to date, but its clinical application is currently limited, due to its low bioavailability and poor solubility in aqueous media $(11 \mathrm{ng} / \mathrm{mL})$. Even high amounts of oral administration $(8 \mathrm{~g} /$ day) of curcumin result in extremely low serum levels $(22-41 \mathrm{ng} / \mathrm{mL})$ in humans [29]. One possible way to enhance the solubility of curcumin in aqueous media, and therefore its bioavailability, is by conjugation with polymers [30,31]. However, the therapeutic dose and the intracellular uptake are not fully established.

Cancer is well recognized as a disease that results from dysregulation of multiple cell signaling pathways [29]. Recent studies indicate that curcumin can interact with a diverse range of molecular targets and affect numerous molecular and biochemical cascades. To this end, transcription factors, cytokines, enzymes, kinases, receptors, and growth factors can be activated by pleiotropic molecules of curcumin [29]. In particular, a multitargeting ability can be a key property in accomplishing the therapeutic activity of curcumin against cancer.

Several signaling mechanisms have been suggested for the action of curcumin in osteosarcoma and other cell types, and the mechanism appears to be cell-type specific. To date, the antitumor activities of curcumin were shown in colorectal carcinoma [32], head and neck squamous cell carcinoma [33], and pancreatic cancer [34], as well as osteosarcoma [35]. It has been reported that expression of genes involved in invasion, metastasis, cell proliferation, apoptosis, and resistance to chemotherapy are modulated by curcumin [36-40]. However, the precise molecular mechanisms of the antitumor activity of curcumin in osteosarcoma still remain unclear.

\subsection{Curcumin-Induced Apoptosis}

Previously, curcumin activity in preventing osteosarcoma cell proliferation was attributed to drug-induced apoptosis [41-43]. A step-by-step examination carried out by Walters et al. using viability and apoptosis assays indicated that curcumin indeed induces apoptosis in osteosarcoma cells [35]. Authors investigated signaling pathways activated by curcumin and confirmed that curcumin-induced apoptosis in different osteosarcoma cell lines involves caspases in the process. Nevertheless, various signaling pathways can be affected by the presence of curcumin [44]. In addition, even a series of signaling events might be involved in curcumin-induced apoptosis of osteosarcoma cells, suggesting that additional signaling pathways might exist.

Recent studies indicate that, in particular, the proteins BAX and Bcl-2 and BAX can be involved in this process. Bcl-2 family proteins are key regulators of apoptosis, while BAX belongs to the pro-apoptotic group [45]. Antiapoptotic effects of $\mathrm{Bcl}-2$ are exerted by mitochondrial cytochrome c release inhibition, while a pro-apoptotic effect of BAX is due to interacting with membrane pore proteins to increase release of cytochrome c [46,47]. Treatment of various osteosarcoma cells resulted in increased cellular levels of BAX and a decreasing cellular level of Bcl-2 [48,49]. Furthermore, the importance of curcumin-induced regulation of Bcl-2 and BAX in drug-induced apoptosis was demonstrated [50,51]. In a study by Walters et al. [35], treatment of osteosarcoma cell lines with curcumin resulted in decreased and increased cellular levels of Bcl-2 and BAX, respectively, indicating that these proteins are important regulators of drug-induced apoptosis in osteosarcoma. 


\subsection{Notch-1 Signaling Mechanism}

Since the Notch signaling pathway plays important roles in human cancer, it has been suggested that specific agents targeting downregulation of Notch signaling can be useful for osteosarcoma treatment. The Notch plays a critical role in proliferation, apoptosis, differentiation, and stem cell maintenance [52], so the Notch signaling pathway may well contribute to osteosarcoma carcinogenesis. The obtained results showed that presence of curcumin leads to osteosarcoma cell death by activating the caspase-3 pathway and blocking cells successively in the G1/S and G2/M phases, as Lee et al. reported [53]. In work by Leow et al., [54] curcumin showed anti-invasive and antimetastatic effects towards intrinsic and extrinsic activation of the $\mathrm{Wnt} / \mathrm{b}$-catenin pathway, in part mediated by downregulating matrix metalloproteinase-9 (MMP-9). Previous reports about Notch-1 cross-talking with MMPs involved in metastasis and cancerous cell invasion have been published $[55,56]$. To this end, MMP expression was reduced by downregulation of Notch-1 [57-59]. Motivated by these observations, Li et al. investigated whether curcumin could inhibit the Notch signaling in osteosarcoma cells and how it might be related to various Notch-responsive genes [18]. Authors assessed the antitumor activity of curcumin using three different osteosarcoma cell lines (U2OS, SaOS-2, and MG-63), to see whether downregulation of Notch-1 is critical in curcumin-induced inhibition of proliferation and invasion in osteosarcoma cells. The results show that curcumin indeed exhibits inhibitory effects on cell proliferation and invasion via suppression of Notch-1 signaling, accompanied by downregulation of Hes-1, cyclin D1, MMP-2, and MMP-9. Moreover, Notch-1 specific downregulation via small-interfering RNA prior to curcumin treatment resulted in cell growth inhibition and invasion. It is clear that the novel mechanism of curcumin antitumor activity involves inactivation of the Notch-1 signaling pathway. Data obtained by Li et al. provided, for the first time, evidence for Notch-1 downregulation by curcumin as an effective mechanism for osteosarcoma treatment by this drug.

\subsection{Effects of Curcumin on Normal Cells}

There are differential effects of curcumin on normal cells, including lymphocytes, fibroblasts, thymocytes, mammary epithelial cells, and hepatocytes [60-66]. Several reasons have been suggested for the ability of curcumin to kill tumor cells but not normal cells, although this process is not fully understood. Kunwar et al. demonstrated that uptake of curcumin in tumor cells is higher than in normal cells [67]. Furthermore, uniform distribution of curcumin in the cell nucleus and membrane has been detected by this group using fluorescence spectroscopy. Another factor contributing to targeted activity of curcumin in tumor cells can be an enhanced sensitivity of cancer cells to this drug due to lower levels of glutathione, as reported by Syng-Ai et al. [61]. In addition, normal cells do not express active NF- $\mathrm{kB}$ as most cancer cells do, mediating their survival [68]. Curcumin can suppress gene products regulated by NF- $\mathrm{kB}$ and, in this way, suppress the proliferation and survival of tumor cells. In this regard, curcumin did not show cytotoxicity in normal rat hepatocytes, and no cell death has been observed [61]. Primary human cultures of fibroblasts were also found to be much less sensitive to lower doses of drugs [64], although curcumin caused fibroblasts' apoptosis to be inhibited by the presence of antioxidants, as reported by Scharstuhl et al. [69]. Ravindran et al., in their review, have shown that, in general, curcumin can kill a broad variety of cancerous cells using diverse mechanisms, but not normal cells [28]; however, they mentioned the necessity of additional studies to gain the full benefits from curcumin in tumor treatment. At the same time, some studies demonstrated that normal osteoblast cells might be killed by curcumin as well. Chan et al. have shown that osteoblast apoptosis occurs at a low concentration of curcumin (up to $25 \mu \mathrm{M}$ ), and when the concentration is increased up to $200 \mu \mathrm{M}$, necrosis was detected [70]. In this regard, the critical information is which concentration of curcumin is not toxic to normal osteoblasts but kills different osteosarcoma cell lines. Such a study was recently carried out by Chang et al. [71]. In this work, the cytotoxicity of curcumin presented at different concentrations $(5-100 \mu \mathrm{M})$ was compared between MG-63 osteosarcoma cells and normal human osteoblasts (HOBs). The obtained results show that MG-63 osteosarcoma cells are much more sensitive to the drug, with high viability of HOBs after $24 \mathrm{~h}$ of the experiment. To this end, it appears that 
curcumin indeed possesses a selective ability to kill osteosarcoma cells but not HOBs. Nevertheless, a proper curcumin delivery system as shown below (carrier) could help overcome its poor solubility in water and bioavailability, and enhance the potential of this drug against osteosarcoma.

\section{Polymeric Micelles as a Platform for Drug Delivery}

The poor solubility of many drugs and drug candidates is one of the main problems encountered when formulating clinically useful pharmaceuticals [72-74]. In the past two decades, over 90 chemotherapeutic drugs have been approved by the U.S. Food and Drug Administration for clinical applications, but the efficacy of these drugs has been dramatically hindered due to ineffective delivery systems. The premier drug delivery nanoparticle presently in use is the liposome [75]. The Doxil $^{\mathrm{TM}}$ (Ben Venue Laboratories, Bedford, OH, USA) formulation, for example, contains a powerful and toxic chemotherapeutic-doxorubicin-incorporated into liposomes, and is approved for the treatment of Kaposi's sarcoma, metastatic breast cancer, and recurrent ovarian cancer [76]. However, due to their hydrophilic interior, liposomes are best suited for the delivery of water-soluble agents and have highly limited loading capacity for poorly water-soluble drugs, as these are not readily entrapped within the hydrophobic bilayer of the liposomes [77]. In addition, most liposomes are larger than $100 \mathrm{~nm}$ in diameter, which hinders their transport into tumor tissues. Polymeric micellar assemblies with hydrophobic cores provide a carrier environment that can encapsulate poorly water-soluble hydrophobic anticancer drugs. The size of these assemblies is typically 10-100 nm and can be precisely controlled by varying the structure of the amphiphilic polymers by the choice of the length of the hydrophobic blocks. The available size range, compared to that of liposomes, prevents losses by renal filtration while allowing increased tumor penetration [78]. Controlled release of the therapeutic agent from the assemblies is also highly desirable to achieve the required level of cytotoxicity upon entry to the tumor site.

Amphiphilic block copolymers usually form polymeric micelles consisting of hydrophilic and hydrophobic fragments, due to their ability to self-assemble in aqueous solutions [79,80]. The driving force for this self-assembly is a hydrophobic interaction that leads to the formation of micellar polymeric architectures with a hydrophobic interior and a hydrophilic stabilizing exterior [81-83]. Micellization behavior, drug encapsulation, and the application of polymer micelles for drug delivery have attracted considerable recent interest [84,85]. Polymeric micelles can effectively accommodate (solubilize) hydrophobic substances by physically entrapping them in the hydrophobic interior [86-89]. Therefore, they are ideally suited for the delivery of insoluble drugs [90,91]. A number of recent studies have proposed block-copolymer assemblies as carriers for anticancer agents or other targeted therapeutics [92-94]. The hydrophobic micellar core is expected to regulate the retention and release of loaded drug molecules at an appropriate time scale $[95,96]$. The structures of amphiphilic block copolymers often include poly(ethylene oxide) (PEO) as the hydrophilic group of choice [97,98]. The length of the hydrophobic block is then chosen to be close to or lower than that of the PEO block. A variety of polymers have been used as hydrophobic interior-forming blocks [99-101]. Amphiphilic block copolymers made from PEO and poly(propylene oxide) (PPO) blocks (Pluronics) have also been evaluated in numerous studies as promising carrier systems for drug and gene delivery [102-104]. The noncovalent incorporation of the cargo into a hydrophobic block-copolymer core has been shown to increase the drug solubility and stability, as well as the circulation of the drug throughout the body [105]. Pluronics can exist in the form of unimers and of micelles encapsulating the solubilized drug; in fact, Pluronic unimers can themselves act as modifiers of biological responses by binding to the cell membrane, thereby altering membrane microviscosity and inhibiting the activity of select membrane proteins [106]. These multiple effects all emanate from the block copolymer's interaction with the biomembrane. No specific copolymer sites exist for binding with specific cellular molecules, which implies a critical role for unspecific interactions between copolymers and biomembranes.

Different internalization pathways for polymeric unimers and aggregates have recently been demonstrated [107]. The Pluronic unimers enter cells rather selectively; a possible explanation for 
this phenomenon is that the more hydrophobic fragments of Pluronics recognize the cholesterol-rich domains of the cellular membrane. This selectivity may originate from differences in the binding energy of the polymer units in the block copolymer chain (the hydrophobic and hydrophilic fragments typically are distributed along the macromolecule). The Pluronics reversibly bind to the membrane, with an exchange occurring between unbound and membrane-bound macromolecules. Optimal binding species therefore can only be identified after multiple trials [108]. One recent study showed that poly(ethylene glycol)-polyester micelle-biomembrane interactions allowed the effective transfer of a core-loaded hydrophobic cargo to the plasma membrane, from which it could either endocytose or diffuse to targets or specific intracellular structures [109].

Much effort has been expended in the design of block copolymer platforms for drug delivery, but researchers still face challenges, such as low drug loading capacity, reduced targeting ability, short in vivo stability, and uncontrolled (non-sustained) drug release [110,111]. The future block-copolymer based delivery systems will require novelty in their macromolecular design, such as inclusion of targeting moieties that can enhance cellular uptake, particularly through receptor-mediated endocytosis, and the drug carriers will need stimulus-responsive features at the site of action. These systems belong to the second generation of polymer-based therapeutics, with properties that will improve their efficiency and reduce adverse side effects [112].

Using a solid dispersion method, micelles of poly(ethylene glycol)- $b$-poly( $\varepsilon$-caprolactone-cop-dioxanone) were loaded with curcumin in a study by Song et al. [113]. The obtained results show that micellar loading capacity was about $12 \mathrm{wt} \%$, and more than $95 \%$ of the curcumin had been successfully incorporated into the micelles. No burst release of the drug was observed, whereas $80 \mathrm{wt} \%$ of curcumin was released within $300 \mathrm{~h}$ of the experiment. Other work from this group reports synthesis of a poly(D,L-lactide-co-glycolide)-b-poly(ethylene glycol)- $b$-poly(D,L-lactide-co-glycolide) (PLGA-PEG-PLGA) triblock copolymer using PEG as macroinitiator of ring opening polymerization of D,L-lactide [114]. Critical micelle concentration of the PLGA-PEG-PLGA was determined to be $0.03 \mathrm{mg} / \mathrm{mL}$. The synthesized triblock copolymer forms spherical micelles with a size of $30 \mathrm{~nm}$ in diameter, determined using transmission electron microscopy and dynamic light scattering measurements. Micellar loading capacity of PLGA-PEG-PLGA micelles was $4 \% w / w$, and $70 \%$ of curcumin amount was incorporated into the micelles. The study did not report on the release experiment, but evaluated pharmacokinetic and biodistribution of curcumin-loaded micelles in vivo. The micelles with a drug were able to pass through the vascular endothelium, reach pulmonary alveoli, and accumulate in the lungs. Mixed micelles from Pluronics polymers F68 and P123 were formed for curcumin incorporation in a study by Zhao et al. [115]. F68/P123 mixed micelles showed a size of about $70 \mathrm{~nm}$ with a loading capacity of $7 \mathrm{wt} \%$ More than $85 \%$ of the curcumin was loaded into the micelles, which demonstrated the sustained release profile by releasing about a half of the loaded curcumin amount within three days of the experiment. Experiments on the molecular dynamics of curcumin interactions with Pluronics copolymers were carried out by Samantha et al. [116]. This study confirms that molecules of curcumin interact predominantly with the more hydrophobic poly(propylene oxide) fragments in Pluronics, while the more hydrophilic PEG sequences serve as a micellar outer part, so that curcumin becomes solvated in an aqueous environment. Using a solid dispersion method, micelles with an average diameter of about $30 \mathrm{~nm}$ from monomethyl poly(ethylene glycol)-poly( $\varepsilon$-caprolactone) (MPEG-PCL) were loaded with curcumin in study by Gong et al. $[117,118]$. The formed micelles were dispersible in water after freeze drying. The obtained results show that micellar loading capacity was about $15 \mathrm{wt} \%$, and more than $99 \%$ of the curcumin had been incorporated into the micelles. In a dialysis experiment using phosphate buffered saline and $0.5 \%$ of Tween 80 , about $60 \mathrm{wt} \%$ of curcumin was released within 14 days of the experiment. The cosolvent evaporation technique was used by Ma et al. to load curcumin in micelles from various PEO-PCL block copolymers [119]. The highest loading capacity was reported for PEO (fragment molecular weight, 5000)-PCL(fragment molecular weight 24,500) copolymer, although the most sustained release was observed for a block copolymer made from $\mathrm{PEO}_{5000}$ and $\mathrm{PCL}_{13,000}$. The authors observed faster release in the experiments 
where human serum albumin was presented, and explained the latter observation by a higher affinity of curcumin to the protein. Using a co-solvent evaporation method, curcumin as a therapeutic and pifitrin as a sensitizer were incorporated in micelles of miktoarm star polymers PEG $_{2}-P C L$ [120]. This work reported on a significant increase in aqueous solubility of curcumin and high efficiency in causing glioblastoma cell death. In the study by Yang et al. [121], curcumin was loaded into micelles of monomethyl poly(ethylene glycol)-poly( $\varepsilon$-caprolactone)-poly(trimethylene carbonate). The developed micelles had a particle size of $27.6 \pm 0.7 \mathrm{~nm}$, drug loading of $14.07 \% \pm 0.94 \%$, encapsulation efficiency of $96.08 \% \pm 3.23 \%$ and were much more effective than free curcumin in inhibiting growth of CT26 colon tumor.

\section{Invertible Polymer Micelles as a Safe Way to Treat Osteosarcoma}

Micellar polymeric assemblies from amphiphilic invertible macromolecules represent a new polymer class, synthesized in our group to study polymer-mediated curcumin delivery to treat osteosarcoma [122-128]. The macromolecules of amphiphilic invertible polymers (AIPs) are made from a precisely controlled number of hydrophilic and hydrophobic short fragments with a well-defined length, alternately distributed in a macromolecular backbone. Incompatibility of these short macromolecular fragments results in microphase separation at smaller-length scale, as compared to block copolymers' structure. The latter in turn enables a greater degree of control in micellar formation [122-125].

Our studies show that AIP macromolecules self-assemble into invertible micellar assemblies in response to changing polarity of the environment, polymer structure, and concentration (Figure 1) [122-126]. The alternated distribution of hydrophilic and lipophilic fragments in the macromolecular backbone facilitates additional control over the self-assembly. The varying hydrophilic-lipophilic balance (HLB) influences surface activity and self-assembly considerably [122-125]. Micellar polymer assemblies from AIPs can accommodate the lipophilic "guest" molecules in their interior and transfer the hydrophobic cargo from water to the less polar phase $[123,124]$. The amount of the transferred payload depends primarily on micellar loading capacity, but most of the loaded cargo molecules have been successfully delivered through the polar-non-polar interface by micellar assemblies [123,124]. To demonstrate the capability of the micellar assemblies to deliver lipophilic drugs, and release the payload using stimuli-responsive inversion of macromolecules, they were loaded with poorly water-soluble curcumin. Knowing that curcumin possesses a great potential in the treatment of diverse diseases, including cancer, but its clinical development is significantly hindered due to the aqueous instability of this drug, using micellar assemblies from AIPs was seen as a tool to address this issue by improving its aqueous solubility and bioavailability.
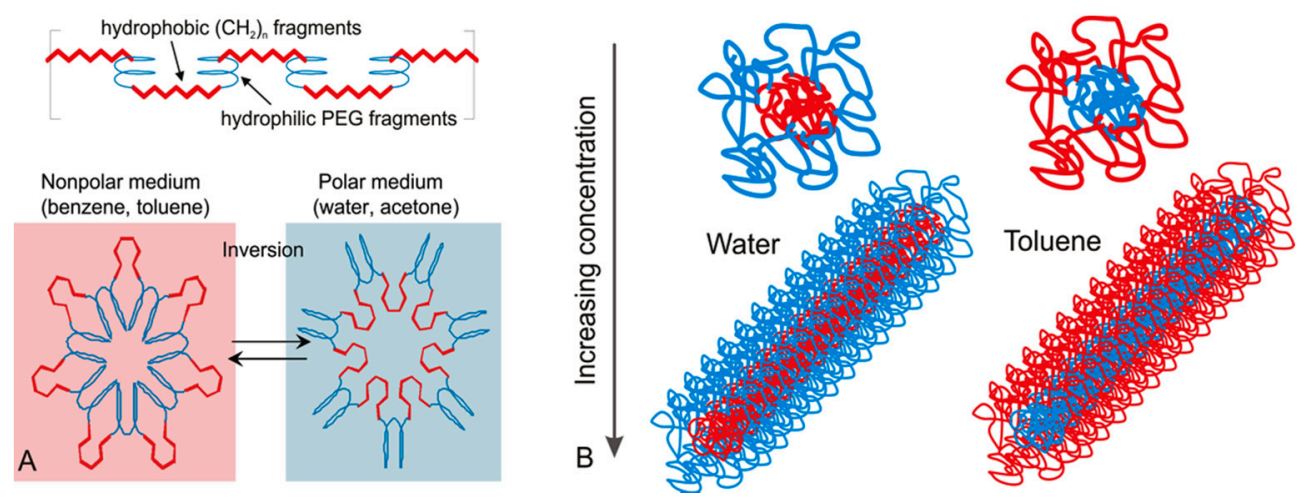

Figure 1. Amphiphilic invertible polymer and micelle structures (A) and micellar self-assembly (B) in polar and nonpolar solvents (reprinted with permission from [128]. Copyright 2011, American Chemical Society). 


\subsection{Self-Assembly of Invertible Macromolecules}

AIPs possess a unique ability to undergo reversible changes in conformation in response to the changing polarity of the environment. Using poly(ethylene glycol) (PEG) as the hydrophilic constituent and aliphatic dicarboxylic (sebacic and dodecanedioic) acids as the hydrophobic constituent, or a combination of PEG and polytetrahydrofuran (PTHF) as the hydrophobic constituent, several AIP libraries have been synthesized [122-127]. The syntheses have been performed through a polycondensation that results in alternating invertible amphiphilic polyester macromolecules with various ratios of hydrophilic and hydrophobic constituents (a series of samples with different HLBs). The characteristics of four representative invertible polymers are shown in Figure 2.

\begin{tabular}{|c|c|c|c|c|c|c|}
\hline \multicolumn{5}{|c|}{$\mathrm{PEG}_{600} \mathrm{PTHF}_{650}, \mathrm{PEG}_{300} \mathrm{PTHF}_{250}$} & \multicolumn{2}{|c|}{ D10, S10 } \\
\hline AIP & $\mathbf{m}$ & $\mathbf{n}$ & HLB & $\mathbf{M}_{\mathbf{w}}$ & PDI & $\mathrm{CMC}, \mathrm{mg} / \mathrm{L}$ \\
\hline $\mathrm{PEG}_{600} \mathrm{PTHF}_{650}$ & 13.2 & 8.8 & 13.8 & 9,700 & 1.52 & 3.5 \\
\hline $\mathrm{PEG}_{300} \mathrm{PTHF}_{250}$ & 6.4 & 3.2 & 14.9 & 12,000 & 1.45 & 9.4 \\
\hline D10 & 22.3 & 10 & 14.4 & 7,600 & 1.53 & 33 \\
\hline S10 & 22.3 & 8 & 15.4 & 11,700 & 1.59 & 490 \\
\hline
\end{tabular}

Figure 2. Chemical structure and characteristics of the representative AIPs. D10 is made from dodecanedioic acid and polyethylene glycol with an average Mn $1000 \mathrm{~g} / \mathrm{mol}$ (PEG-1000). S10 is based on PEG-1000 and sebacic acid. The subscripted numbers indicate the average molecular weight of the copolymerized PEG and polytetrahydrofuran (PTHF) in the PEG-PTHF copolymers (reprinted with permission from [124], Copyright 2012, American Chemical Society).

The AIP macromolecules form micelles in different solvents and demonstrate a unique switching behavior when the solvent polarity is changed (Figure 1) [122-127]. In a polar medium, PEG (blue) forms the outer layer of the micellar architecture, and the hydrophobic fragments $(\mathrm{red})$ are collapsed and screened in the micellar interior. The ability of the synthesized amphiphilic macromolecules to invert their conformation in response to changes in solvent polarity has been confirmed by viscosity measurements, ${ }^{1} \mathrm{H}$ NMR spectroscopy, and small-angle neutron scattering (SANS) techniques [122,125].

A combined ${ }^{1} \mathrm{H}$ NMR/SANS study has demonstrated that single AIP micelles aggregate and form supramolecular micellar assemblies by increasing the polymer concentration in an aqueous medium. The polymer micelles self-assemble and form nanostructures containing hydrophilic and lipophilic domains with AIP increasing concentrations at ambient temperature [122-127]. Changing the length and the ratio of the fragments in the amphiphilic macromolecule results in changes in the AIP surface activity in an aqueous solution. Even slight changes in the ratio of the sizes of the two (hydrophobic and/or hydrophilic) fragments have been conclusively shown to lead to remarkable differences in behavior of amphiphilic invertible macromolecules in response to concentration and polarity changes [122,125].

To obtain detailed quantitative parameters of the formed nanostructures, SANS measurements and their fitting according to a core-shell cylindrical model were applied. The size and detailed composition of the micellar assemblies (including the effect of temperature on the size and composition of the assemblies) were measured in aqueous and toluene polymer solutions [125]. It was shown that AIP unimers self-assemble in aqueous solution predominantly through segregation of macromolecular fragments and the microphase separation. The longer - $\left(\mathrm{CH}_{2}\right)_{10}-$ fragments of dodecanedioic acid undergo stronger interactions compared to shorter $-\left(\mathrm{CH}_{2}\right)_{8}-$ sebacic acid fragments. The latter results in closer packing of fragments in the core and formation of smaller micellar assemblies [125]. To demonstrate the inversion mechanism of AIP micellar assemblies, scattering contrast and the known scattering length densities of the solvents and the polymer components have been used [125]. It was shown that PEG and the aliphatic dicarboxylic acid fragments of the AIP macromolecule indeed tend 
to replace each other in the core and shell of the assemblies in response to changes in the polarity of the environmental medium from polar to nonpolar (Figure 3). Furthermore, using various dyes, the ability of AIP micelles to solubilize otherwise insoluble substances, both in polar and nonpolar solvents, was demonstrated. The dyes were immediately extracted into the solvent phase, either water or toluene, in the presence of micellar assemblies, as indicated by the clear changes in the solution color [123].

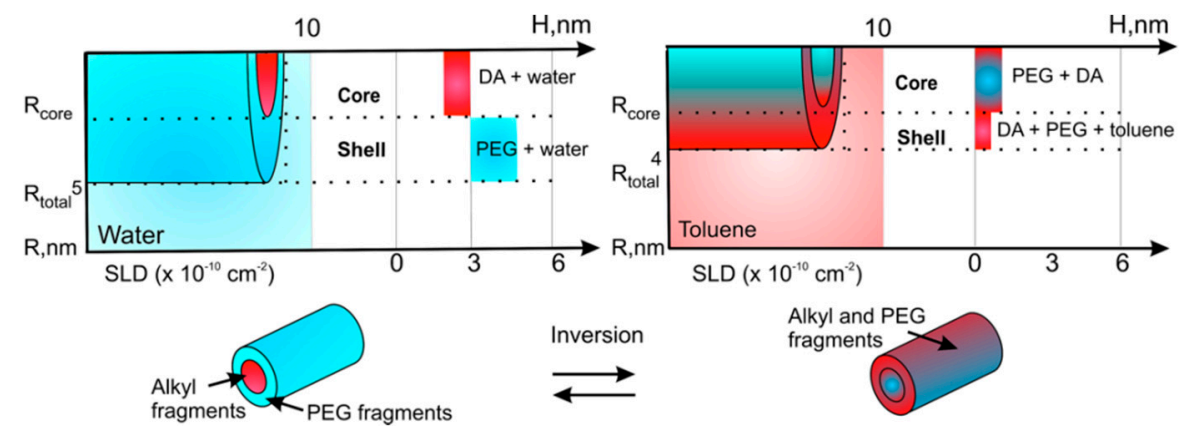

Figure 3. Scheme of the inversion for D3 (DA—-dodecanedioc acid moiety) (reprinted with permission from [125], American Chemical Society).

By altering the molecular weight and ratio of the fragments in the macromolecule, solubility of AIPs in polar and nonpolar solvents can be adjusted. Highly hydrophobic drug molecules can be physically incorporated within the interior of the AIP micellar assemblies through hydrophobic interactions in an aqueous solution. This micellar inversion can be promising for rapid and controlled self-assembly in applications that require simultaneous utility in polar and nonpolar media, e.g., in drug delivery.

\subsection{Micellar Assembly Mediated Curcumin Delivery to Osteosarcoma Cells}

Upon adsorption onto the osteosarcoma cell surface, the AIP assemblies with incorporated curcumin molecules were expected to change their conformation and release their cargo (curcumin) for transport into the membrane. For this purpose in the experiments, micellar curcumin was prepared using 1\% polymer solutions (Table 1). At this concentration, the AIP micelles are self-assembled into the assemblies, and the curcumin is solubilized through physical interactions with the polymer hydrophobic fragments of the micellar interior [124].

Table 1. Physical properties of blank and curcumin-loaded micellar assemblies at $1 \%$ concentration.

\begin{tabular}{|c|c|c|c|c|c|}
\hline AIP & Loading, wt \% & $\begin{array}{l}\text { Size, nm } \\
\text { (Blank) }\end{array}$ & $\begin{array}{l}\text { Size, } \mathrm{nm} \\
\text { (Loaded) }\end{array}$ & $\begin{array}{c}\zeta \text {-Potential, } \mathrm{mV} \\
\text { (Blank) }\end{array}$ & $\begin{array}{c}\zeta \text {-Potential, mV } \\
\text { (Loaded) }\end{array}$ \\
\hline PEG $_{600}$ PTHF $_{650}$ & $10.3 \pm 0.4$ & $12.0 \pm 0.2$ & $17.5 \pm 2.6$ & $-24.2 \pm 3.8$ & $-18.2 \pm 0.6$ \\
\hline PEG $_{300}$ PTHF $_{250}$ & $3.6 \pm 0.3$ & $12.4 \pm 0.2$ & $18.4 \pm 1.1$ & $-43.0 \pm 2.3$ & $-42.6 \pm 1.5$ \\
\hline D10 & $1.9 \pm 0.3$ & $6.3 \pm 0.3$ & $7.8 \pm 0.6$ & $-10.3 \pm 0.9$ & $-7.4 \pm 0.3$ \\
\hline S10 & $0.14 \pm 0.03$ & $3.3 \pm 0.5$ & $3.6 \pm 0.2$ & $-7.1 \pm 0.3$ & $-6.7 \pm 0.9$ \\
\hline
\end{tabular}

Table 1 shows the curcumin loading content for each micellar formulation that was investigated. For the four chosen polymers, the hydrodynamic diameters of the micellar assemblies vary between $4.7 \pm 0.2 \mathrm{~nm}$ and $12 \pm 0.6 \mathrm{~nm}$. The hydrodynamic diameter size is larger for the loaded micellar assemblies in comparison to assemblies without curcumin, which confirms that the drug is incorporated into the micellar interior. Narrow micellar size distribution and small size of the assemblies indicate that they possess good physical properties to be considered as nanocarriers in delivery of drugs which are poorly water-soluble. The obtained results demonstrate that the highest amount of solubilized curcumin in the micellar assemblies is obtained with the most hydrophobic PEG $_{600} \mathrm{PTHF}_{650}$ 
(HLB = 13.9). Using MTS (3-(4,5-dimethylthiazol-2-yl)-5-(3-carboxymethoxyphenyl)-2-(4-sulfophenyl)2H-tetrazolium) assays for different concentrations of loaded assemblies, the effect of micellar assembly-mediated curcumin delivery on osteosarcoma cell survival was investigated.

The obtained results show that three human osteosarcoma cell lines: MG63 (treated with different concentrations of micellar curcumin, Figure 4A), KHOS, and LM7 (Figure 4B) demonstrated essentially reduced cell survival in the presence of micellar curcumin. Remarkably, the blank polymer micelles had no effect on the survival of normal cells, when tested at the same concentrations.
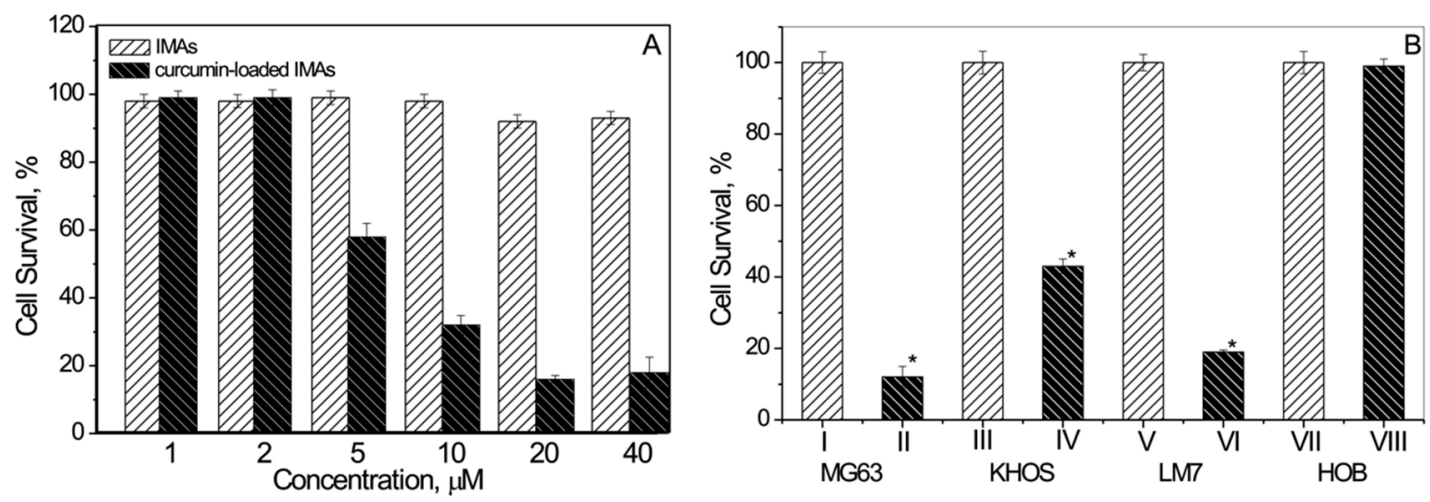

Figure 4. Osteosarcoma cell survival. MG63 osteosarcoma cells were treated with non-loaded micellar assemblies and micellar curcumin at different concentrations for $48 \mathrm{~h}$ (A); The effect of curcumin delivery on MG63 KHOS, LM7, and HOB cells at 72 h (B). Non-loaded micellar assemblies: I, III, V, VII; curcumin-loaded assemblies: II, IV, VI and VIII (from [126]).

This indicates that the micellar assemblies effectively delivered curcumin and targeted three different bone cancer cells (MG63, KHOS, and LM7) but did not impact normal primary human osteoblast HOBs (Figure 4B).

These studies are comparable to the findings by Chang et al. [71]. It appears that a delivery system could help minimize the toxic effects observed by other investigators which show that curcumin at low concentration induces apoptosis and at high concentration induces necrosis in normal osteoblasts [70].

Thus, based on AIP, micellar-assembly delivered curcumin kills various osteosarcoma (cancer) cells by specifically targeting osteosarcoma cells and shows no effect on normal bone cells. The latter finding indicates that AIP-micellar assembly based delivery can be a powerful approach for the targeted delivery of poorly-soluble curcumin in bone cancer cells.

Differential effects of micellar curcumin in osteosarcoma and normal osteoblast cells were investigated next, by following the uptake of loaded and non-loaded micellar assemblies. When delivered by micellar assemblies, the curcumin was readily taken up, as confocal microscopy studies (Figure 5) confirms. The drug was seen in the cytoplasm within 30 min and could still be seen after two hours (Figure 5, top row). Based on confocal microscopy data, it was additionally confirmed that micellar assemblies are able to deliver the drug effectively and target bone cancer cells (MG63, KHOS, and LM7 cells), but not HOBs (Figure 5, bottom row).

The AIP micellar study shows the potential of assemblies from amphiphilic invertible macromolecules to be a promising platform for controlled delivery of poorly water-soluble curcumin to osteosarcoma cells, and to release the drug using a new and unexplored inversion mechanism. To reveal the nature of this novel and unique mechanism and its value in a treatment for bone cancer, further experiments are currently planned. 

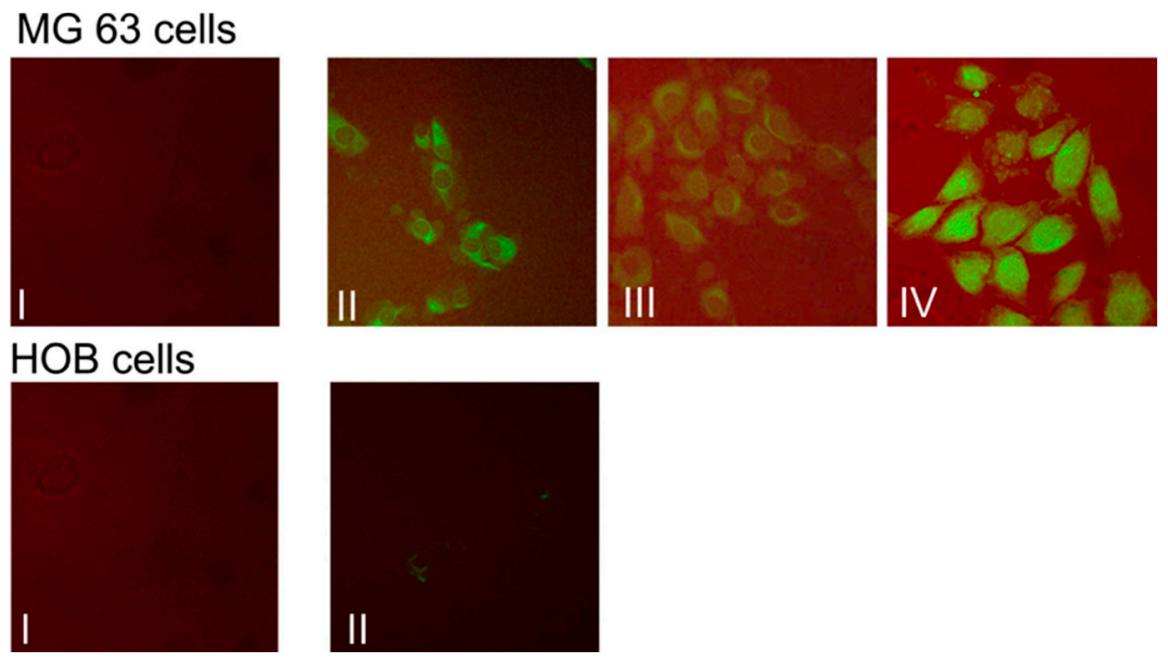

Figure 5. Micellar curcumin uptake in bone cells; $20 \mu \mathrm{M}$ non-loaded assemblies (I) and micellar curcumin (II-IV) were exposed to MG63 osteosarcoma cells and normal human osteoblasts (HOB) for $30 \mathrm{~min}$ (I, II); $1 \mathrm{~h}$ (III), and $2 \mathrm{~h}$ (IV) (from [126]).

\section{Conclusions}

The drug release platform of the proposed polymeric carriers relies on switching (inversion) of the micellar architectures formed upon self-assembly in response to changing environmental polarity. Several stimulus-responsive strategies for drug release from polymeric micelles have been explored previously, including $\mathrm{pH}$, temperature, and ultrasound, but it is expected that macromolecular inversion will prove more beneficial. It will facilitate carrier-cell interactions and enhance targeted drug release from the micellar assembly core into the cell membrane. However, the efficiency and robustness of this drug-delivery strategy can only be achieved when we fully understand the mechanisms of macromolecular inversion in response to environmental changes and all possible pathways of invertible micelle-cell interactions.

Author Contributions: The whole process of preparation of this review has been initiated and guided by Andriy Voronov, while Avudaiappan Maran, Michael J. Yaszemski and Ananiy Kohut wrote the original version of the manuscript.

Conflicts of Interest: The authors declare no conflict of interest.

\section{References}

1. Arndt, C.A.; Crist, W.M. Common musculoskeletal tumors of childhood and adolescence. N. Engl. J. Med. 1999, 341, 342-352. [CrossRef] [PubMed]

2. Hayden, J.B.; Hoang, B.H. Osteosarcoma: Basic science and clinical implications. Orthop. Clin. N. Am. 2006, 37, 1-7. [CrossRef] [PubMed]

3. Kansara, M.; Thomas, D.M. Molecular pathogenesis of osteosarcoma. DNA Cell Biol. 2004, 26, 1-18. [CrossRef] [PubMed]

4. Marina, N.; Gebhardt, M.; Teot, L.; Gorlick, R. Biology and therapeutic advances for pediatric osteosarcoma. Oncologist 2004, 9, 422-441. [CrossRef] [PubMed]

5. Bielack, S.S.; Kempf-Bielack, B.; Delling, G.; Exner, G.U.; Flege, S.; Helmke, K.; Kotz, R.; Salzer-Kuntschik, M.; Werner, M.; Winkelmann, W.; et al. Prognostic factors in high-grade osteosarcoma of the extremities or trunk: An analysis of 1702 patients treated on neoadjuvant cooperative osteosarcoma study group protocols. J. Clin. Oncol. 2002, 20, 776-790. [CrossRef] [PubMed]

6. O'Reilly, R.; Cheung, N.K.; Bowman, L.; Castle, V.; Hoffer, F.; Kapoor, N.; Kletzel, M.; Lindsley, K.; Shamberger, R.; Tubergen, D. NCCN pediatric neuroblastoma practice guidelines. The National Comprehensive Cancer Network. Oncology (Williston Park) 1996, 10, 1813-1822. [PubMed] 
7. Ward, W.G.; Mikaelian, K.; Dorey, F.; Mirra, J.M.; Sassoon, A.; Holmes, E.C.; Eilber, F.R.; Eckardt, J.J. Pulmonary metastases of stage IIB extremity osteosarcoma and subsequent pulmonary metastases. J. Clin. Oncol. 1994, 12, 1849-1858. [PubMed]

8. Arndt, C.A.; Rose, P.S.; Folpe, A.L.; Laack, N.N. Common musculoskeletal tumors of childhood and adolescence. Mayo Clin. Proc. 2012, 87, 475-487. [CrossRef] [PubMed]

9. Iwamoto, Y.; Tanaka, K. The activity of the Bone and Soft Tissue Tumor Study Group of the Japan Clinical Oncology Group. Jpn. J. Clin. Oncol. 2012, 42, 467-470. [CrossRef] [PubMed]

10. Baum, E.S.; Gaynon, P.; Greenberg, L.; Krivit, W.; Hammond, D. Phase II trail cisplatin in refractory childhood cancer: Children's cancer study group report. Cancer Treat. Rep. 1981, 65, 815-822. [PubMed]

11. Smith, M.A.; Ungerleider, R.S.; Horowitz, M.E.; Simon, R. Influence of doxorubicin dose intensity on response and outcome for patients with osteogenic sarcoma and Ewing's sarcoma. J. Nat. Cancer Inst. 1991, 83, 1460-1470. [CrossRef] [PubMed]

12. Meistrich, M.L.; Chawla, S.P.; da Cunha, M.F.; Johnson, S.L.; Plager, C.; Papadopoulos, N.E.; Lipshultz, L.I.; Benjamin, R.S. Recovery of sperm production after chemotherapy for osteosarcoma. Cancer 1989, 63, 2115-2123. [CrossRef]

13. Goorin, A.M.; Shuster, J.J.; Baker, A.; Horowitz, M.E.; Meyer, W.H.; Link, M.P. Changing pattern of pulmonary metastases with adjuvant chemotherapy in patients with osteosarcoma: Results from the multiinstitutional osteosarcoma study. J. Clin. Oncol. 1991, 9, 600-605. [PubMed]

14. Kunchandy, E.; Rao, M.N.A. Oxygen radical scavenging activity of curcumin. Int. J. Pharm. 1990, 58, $237-240$. [CrossRef]

15. Chan, M.M.; Huang, H.I.; Fenton, M.R.; Fong, D. In vivo inhibition of nitric oxide synthase gene expression by curcumin, a cancer preventive natural product with anti-inflammatory properties. Biochem. Pharmacol. 1998, 55, 1955-1962. [CrossRef]

16. Gota, V.S.; Maru, G.B.; Soni, T.G.; Gandhi, T.R.; Kochar, N.; Agarwal, M.G. Safety and pharmacokinetics of a solid lipid curcumin particle formulation in osteosarcoma patients and healthy volunteers. J. Agric. Food Chem. 2010, 58, 2095-2099. [CrossRef] [PubMed]

17. Jin, S.; Xu, H.G.; Shen, J.N.; Chen, X.W.; Wang, H.; Zhou, J.G. Apoptotic effects of curcumin on human osteosarcoma U2OS cells. Orthop. Surg. 2009, 1, 144-152. [CrossRef] [PubMed]

18. Li, Y.; Zhang, J.; Ma, D.; Zhang, L.; Si, M.; Yin, H.; Li, J. Curcumin inhibits proliferation and invasion of osteosarcoma cells through inactivation of Notch-1 signaling. FEBS J. 2012, 279, 2247-2259. [CrossRef] [PubMed]

19. Ma, D.; Tremblaym, P.; Mahngar, K.; Collins, J.; Hudlicky, T.; Pandey, S. Selective cytotoxicity against human osteosarcoma cells by a novel synthetic C-1 analogue of 7-deoxypancratistatin is potentiated by curcumin. PLoS ONE 2001, 6, e28780. [CrossRef] [PubMed]

20. Reuter, S.; Eifes, S.; Dicato, M.; Aggarwal, B.B.; Diederich, M. Modulation of anti-apoptotic and survival pathways by curcumin as a strategy to induce apoptosis in cancer cells. Biochem. Pharmacol. 2008, 76, 1340-1351. [CrossRef] [PubMed]

21. Strimpakos, A.S.; Sharma, R.A. Curcumin: Preventive and therapeutic properties in laboratory studies and clinical trials. Antioxid. Redox Signal. 2008, 10, 511-545. [CrossRef] [PubMed]

22. Hatcher, H.; Planalp, R.; Cho, J.; Torti, F.M.; Torti, S.V. Curcumin: From ancient medicine to current clinical trials. Cell. Mol. Life Sci. 2008, 65, 1631-1652. [CrossRef] [PubMed]

23. Sikora, E.; Bielak-Zmijewska, A.; Magalska, A.; Piwocka, K.; Mosieniak, G.; Kalinowska, M.; Widlak, P.; Cymerman, I.A.; Bujnicki, J.M. Curcumin induces caspase-3-dependent apoptotic pathway but inhibits DNA fragmentation factor 40/caspase-activated DNase endonuclease in human Jurkat cells. Mol. Cancer Ther. 2006, 5, 927-934. [CrossRef] [PubMed]

24. Magalska, A.; Brzezinska, A.; Bielak-Zmijewska, A.; Piwocka, K.; Mosieniak, G.; Sikora, E. Curcumin induces cell death without oligonucleosomal DNA fragmentation in quiescent and proliferating human CD8+ cells. Acta Biochim. Pol. 2006, 53, 531-538. [PubMed]

25. Mosieniak, G.; Sliwinska, M.; Piwocka, K.; Sikora, E. Curcumin abolishes apoptosis resistance of calcitriol-differentiated HL-60 cells. FEBS Lett. 2006, 580, 4653-4660. [CrossRef] [PubMed]

26. Wolanin, K.; Magalska, A.; Mosieniak, G.; Klinger, R.; McKenna, S.; Vejda, S.; Sikora, E.; Piwocka, K. Curcumin affects components of the chromosomal passenger complex and induces mitotic catastrophe in apoptosis-resistant Bcr-Abl-expressing cells. Mol. Cancer Res. 2006, 4, 457-469. [CrossRef] [PubMed] 
27. Bielak-Zmijewska, A.; Sikora-Polaczek, M.; Nieznanski, K.; Mosieniak, G.; Kolano, A.; Maleszewski, M.; Styrna, J.; Sikora, E. Curcumin disrupts meiotic and mitotic divisions via spindle impairment and inhibition of CDK1 activity. Cell Prolif. 2010, 43, 354-364. [CrossRef] [PubMed]

28. Ravindran, J.; Prasad, S.; Aggarwal, B.B. Curcumin and cancer cells: How many ways can curry kill tumor cells selectively? AAPS J. 2009, 11, 495-510. [CrossRef] [PubMed]

29. Anand, P.; Sundaram, C.; Jhuran, S.; Kunnumakkara, A.B.; Aggarwal, B.B. Curcumin and cancer: An "old-age" disease with an "age-old" solution. Cancer Lett. 2008, 67, 133-164. [CrossRef] [PubMed]

30. Lan, L.; Fadi, S.B.; Razelle, K. Liposome-encapsulated curcumin. Cancer 2005, 104, 1322-1331.

31. Kunwar, A.; Barik, A.; Pandey, R.; Priyadarsini, K.I. Transport of liposomal and albumin loaded curcumin to living cells: An absorption and fluorescence spectroscopic study. Biochim. Biophys. Acta 2006, 1760, 1513-1520. [CrossRef] [PubMed]

32. Patel, B.B.; Majumdar, A.P. Synergistic role of curcumin with current therapeutics in colorectal cancer: Minireview. Nutr. Cancer 2009, 61, 842-846. [CrossRef] [PubMed]

33. Chakravarti, N.; Kadara, H.; Yoon, D.J.; Shay, J.W.; Myers, J.N.; Lotan, D.; Sonenberg, N.; Lotan, R. Differential inhibition of protein translation machinery by curcumin in normal, immortalized, and malignant oral epithelial cells. Cancer Prev. Res. 2010, 3, 331-338. [CrossRef] [PubMed]

34. Wang, Z.; Zhang, Y.; Banerjee, S.; Li, Y.; Sarkar, F.H. Notch-1 down-regulation by curcumin is associated with the inhibition of cell growth and the induction of apoptosis in pancreatic cancer cells. Cancer 2006, 106, 2503-2513. [CrossRef] [PubMed]

35. Walters, D.K.; Muff, R.; Langsam, B.; Born, W.; Fuchs, B. Cytotoxic effects of curcumin on osteosarcoma cell lines. Investig. New Drugs 2008, 26, 289-297. [CrossRef] [PubMed]

36. Hanif, R.; Qiao, L.; Shiff, S.J.; Rigas, B. Curcumin, a natural plant phenolic food additive, inhibits cell proliferation and induces cell cycle changes in colon adenocarcinoma cell lines by a prostaglandin-independent pathway. J. Lab. Clin. Med. 1997, 130, 576-584. [CrossRef]

37. Dorai, T.; Cao, Y.C.; Dorai, B.; Buttyan, R.; Katz, A.E. Therapeutic potential of curcumin in human prostate cancer. III. Curcumin inhibits proliferation, induces apoptosis, and inhibits angiogenesis of LNCaP prostate cancer cells in vivo. Prostate 2001, 47, 293-303. [CrossRef] [PubMed]

38. Huang, M.T.; Lou, Y.R.; Xie, J.G.; Ma, W.; Lu, Y.P.; Yen, P.; Zhu, B.T.; Newmark, H.; Ho, C.T. Effect of dietary curcumin and dibenzoylmethane on formation of 7,12-dimethylbenz[a]anthracene-induced mammary tumors and lymphomas/leukemias in Sencar mice. Carcinogenesis 1998, 19, 1697-1700. [CrossRef] [PubMed]

39. Fossey, S.L.; Bear, M.D.; Lin, J.; Li, C.; Schwartz, E.B.; Li, P.K.; Fuchs, J.R.; Fenger, J.; Kisseberth, W.C.; London, C.A. The novel curcumin analog FLLL32 decreases STAT3 DNA binding activity and expression, and induces apoptosis in osteosarcoma cell lines. BMC Cancer 2011, 11, 112. [CrossRef] [PubMed]

40. Yu, S.; Shen, G.; Khor, T.O.; Kim, J.H.; Kong, A.N. Curcumin inhibits Akt/mammalian target of rapamycin signaling through protein phosphatase-dependent mechanism. Mol. Cancer Ther. 2008, 7, 2609-2620. [CrossRef] [PubMed]

41. Kuo, M.L.; Huang, T.S.; Lin, J.K. Curcumin, an antioxidant and anti-tumor promoter, induces apoptosis in human leukemia cells. Biochim. Biophys. Acta 1996, 1317, 95-100. [CrossRef]

42. Chen, H.; Zhang, Z.S.; Zhang, Y.L.; Zhou, D.H. Curcumin inhibits cell proliferation by interfering with the cell cycle and inducing apoptosis in colon carcinoma cells. Anticancer Res. 1999, 19, 3675-3680. [PubMed]

43. Mehta, K.; Pantazis, P.; McQueen, T.; Aggarwal, D.H. Antiproliferative effects of curcumin (diferuloylmethane) against human breast tumor cell lines. Anticancer Drugs 1997, 8, 470-481. [CrossRef] [PubMed]

44. Sharma, R.A.; Gescher, A.J.; Steward, W. Curcumin: The story so far. Eur. J. Cancer 2005, 41, $1955-1968$. [CrossRef] [PubMed]

45. Er, E.; Oliver, L.; Cartron, P.-F.; Juin, P.; Manon, S.; Vallette, F.M. Mitochondria as the target of the pro-apoptotic protein Bax. Biochim. Biophys. Acta 2006, 1757, 1301-1311. [CrossRef] [PubMed]

46. Murphy, K.M.; Ranganathan, V.; Farnsworth, M.L.; Kavallaris, M.; Lock, R.B. Bcl-2 inhibits Bax translocation from cytosol to mitochondria during drug-induced apoptosis of human tumor cells. Cell Death Differ. 2000, 7 , 102-111. [CrossRef] [PubMed]

47. Narita, M.; Shimizu, S.; Ito, T.; Chittenden, T.; Lutz, R.J.; Matsuda, H.; Tsujimoto, Y. Bax interacts with the permeability transition pore to induce permeability transition and cytochrome $\mathrm{c}$ release in isolated mitochondria. Proc. Natl. Acad. Sci. USA 1998, 95, 14681-14686. [CrossRef] [PubMed] 
48. Shankar, S.; Srivastava, R.K. Involvement of Bcl-2 family members, phosphatidylinositol 3'-kinase/AKT and mitochondrial p53 in curcumin (diferuloylmethane)-induced apoptosis in prostate cancer. Int. J. Oncol. 2007, 30, 905-918. [PubMed]

49. Mukherjee, N.C.S.; Ghosh, U.; Bhattacharyya, N.P.; Bhattacharya, R.K.; Dey, S.; Roy, M. Curcumin-induced apoptosis in human leukemia cell HL-60 is associated with inhibition of telomerase activity. Mol. Cell Biochem. 2007, 297, 31-39. [CrossRef] [PubMed]

50. Anto, R.J.; Mukhopadhyay, A.; Denning, K.; Aggarwal, B.B. Curcumin (diferuloylmethane) induces apoptosis through activation of caspase-8, BID cleavage and cytochrome $c$ release: Its suppression by ectopic expression of Bcl-2 and Bcl-xl. Carcinogenesis 2002, 23, 143-150. [CrossRef] [PubMed]

51. Shankar, S.; Srivastava, R.K. Bax and Bak genes are essential for maximum apoptotic response by curcumin, a polyphenolic compound and cancer chemopreventive agent derived from turmeric, Curcuma longa. Carcinogenesis 2007, 28, 1277-1286. [CrossRef] [PubMed]

52. Li, J.L.; Harris, A.L. Notch signaling from tumor cells: A new mechanism of angiogenesis. Cancer Cell 2005, 8, 1-3. [CrossRef] [PubMed]

53. Lee, D.S.; Lee, M.K.; Kim, J.H. Curcumin induces cell cycle arrest and apoptosis in human osteosarcoma (HOS) cells. Anticancer Res. 2009, 29, 5039-5044. [PubMed]

54. Leow, P.C.; Tian, Q.; Ong, Z.Y.; Yang, Z.; Ee, P.L. Antitumor activity of natural compounds, curcumin and PKF118-310, as Wnt/beta-catenin antagonists against human osteosarcoma cells. Investig. New Drugs 2010, 28, 766-782. [CrossRef] [PubMed]

55. John, A.; Tuszynski, G. The role of matrix metalloproteinases in tumor angiogenesis and tumor metastasis. Pathol. Oncol. Res. 2001, 7, 14-23. [CrossRef] [PubMed]

56. Stetler-Stevenson, W.G. The role of matrix metalloproteinases in tumor invasion, metastasis, and angiogenesis. Surg. Oncol. Clin. N. Am. 2001, 10, 383-392. [PubMed]

57. Wang, Z.; Banerjee, S.; Li, Y.; Rahman, K.M.; Zhang, Y.; Sarkar, F.H. Down-regulation of notch-1 inhibits invasion by inactivation of nuclear factor-kappaB, vascular endothelial growth factor, and matrix metalloproteinase-9 in pancreatic cancer cells. Cancer Res. 2006, 66, 2778-2784. [CrossRef] [PubMed]

58. Wang, J.; Fu, L.; Gu, F.; Ma, Y. Notch1 is involved in migration and invasion of human breast cancer cells. Oncol. Rep. 2011, 26, 1295-1303. [PubMed]

59. Yu, B.; Wei, J.; Qian, X.; Lei, D.; Ma, Q.; Liu, Y. Notch1 signaling pathway participates in cancer invasion by regulating MMPs in lingual squamous cell carcinoma. Oncol. Rep. 2012, 27, 547-552. [PubMed]

60. Jaruga, E.; Bielak-Zmijewska, A.; Sikora, E.; Skierski, J.; Radziszewska, E.; Piwocka, K.; Bartosz, G. Glutathione-independent mechanism of apoptosis inhibition by curcumin in rat thymocytes. Biochem. Pharmacol. 1998, 56, 961-965. [CrossRef]

61. Syng-Ai, C.; Kumari, A.L.; Khar, A. Effect of curcumin on normal and tumor cells: Role of glutathione and bcl-2. Mol. Cancer Ther. 2004, 3, 1101-1108. [PubMed]

62. Uddin, S.; Hussain, A.R.; Manogaran, P.S.; Al-Hussein, K.; Platanias, L.C.; Gutierrez, M.I.; Bhatia, K.G. Curcumin suppresses growth and induces apoptosis in primary effusion lymphoma. Oncogene 2005, 24, 7022-7030. [CrossRef] [PubMed]

63. Karunagaran, D.; Rashmi, R.; Kumar, T.R. Induction of apoptosis by curcumin and its implications for cancer therapy. Curr. Cancer Drug Targets 2005, 5, 117-129. [CrossRef] [PubMed]

64. Watson, J.L.; Hill, R.; Lee, P.W.; Giacomantonio, C.A.; Hoskin, D.W. Curcumin induces apoptosis in HCT-116 human colon cancer cells in a p21-independent manner. Exp. Mol. Pathol. 2008, 84, 230-233. [CrossRef] [PubMed]

65. Ghoneim, A.I. Effects of curcumin on ethanol-induced hepatocyte necrosis and apoptosis: Implication of lipid peroxidation and cytochrome c. Naunyn. Schmiedebergs Arch. Pharmacol. 2009, 379, 47-60. [CrossRef] [PubMed]

66. Cucuzza, L.S.; Motta, M.; Miretti, S.; Accornero, P.; Baratta, M. Curcuminoid-phospholipid complex induces apoptosis in mammary epithelial cells by STAT-3 signaling. Exp. Mol. Med. 2008, 40, 647-657. [CrossRef] [PubMed]

67. Kunwar, A.; Barik, A.; Mishra, B.; Rathinasamy, K.; Pandey, R.; Priyadarsini, K.I. Quantitative cellular uptake, localization and cytotoxicity of curcumin in normal and tumor cells. Biochim. Biophys. Acta 2008, 1780, 673-679. [CrossRef] [PubMed] 
68. Shishodia, S.; Amin, H.M.; Lai, R.; Aggarwal, B.B. Curcumin (diferuloylmethane) inhibits constitutive NF-kappaB activation, induces G1/S arrest, suppresses proliferation, and induces apoptosis in mantle cell lymphoma. Biochem. Pharmacol. 2005, 70, 700-713. [CrossRef] [PubMed]

69. Scharstuhl, A.; Mutsaers, H.A.; Pennings, S.W.; Szarek, W.A.; Russel, F.G.; Wagener, F.A. Curcumin-Induced Fibroblast Apoptosis and in vitro Wound Contraction Are Regulated by Antioxidants and Heme Oxygenase: Implications for Scar Formation. J. Cell. Mol. Med. 2009, 13, 712-725. [CrossRef] [PubMed]

70. Chan, W.H.; Wu, H.Y.; Chang, W.H. Dosage effects of curcumin on cell death types in a human osteoblast cell line. Food Chem. Toxicol. 2006, 44, 1362-1371. [CrossRef] [PubMed]

71. Chang, R.; Sun, L.; Webster, T.J. Short communication: Selective cytotoxicity of curcumin on osteosarcoma cells compared to healthy osteoblasts. Int. J. Nanomedicine 2014, 9, 461-465. [CrossRef] [PubMed]

72. Yokoyama, M.; Satoh, A.; Sakurai, Y.; Okano, T.; Matsumura, Y.; Kakizoe, T. Incorporation of water-insoluble anticancer drug into polymeric micelles and control of their particle size. J. Control. Release 1998, 55, 219-229. [CrossRef]

73. Batrakova, E.V.; Dorodnych, T.Y.; Klinskii, E.Y.; Kliushnenkova, E.N.; Shemchukova, O.V.; Goncharova, O.N. Anthracycline antibiotics non-covalently incorporated into the block copolymer micelles: In vivo evaluation of anticancer activity. Br. J. Cancer 1996, 74, 1545-1552. [CrossRef] [PubMed]

74. Kabanov, A.V.; Nazarova, I.R.; Astafieva, I.R.; Batrakova, E.V.; Alakhov, V.Y.; Yaroslavov, A.A. Micelle formation and solubilization of fluorescence probes in poly(oxyethylene- $b$-oxypropylene- $b$-oxyethylene) solutions. Macromolecules 1995, 28, 2303-2314. [CrossRef]

75. Kabanov, A.V.; Vinogradov, S.V.; Suzdaltseva, U.G.; Alakhov, V.Y. Water-soluble block polycations as carriers for oligonucleotide delivery. Bioconj. Chem. 1995, 6, 639-643. [CrossRef]

76. Alakhov, V.Y.; Kabanov, A.V. Block copolymeric biotransport carriers as versatile vehicles for drug delivery. Expert Opin. Investig. Drugs 1998, 7, 1453-1473. [CrossRef] [PubMed]

77. Matsumura, Y.; Yokoyama, M.; Kataoka, K.; Okano, T.; Sakurai, Y.; Kawaguchi, T. Reduction of the side effects of an antitumor agent, KRN5500, by incorporation of the drug into polymeric micelles. Jpn. J. Cancer Res. 1999, 90, 122-128. [CrossRef] [PubMed]

78. Torchilin, V.P.; Trubetskoy, V.S. Biodistribution of surface-modified liposomes and particles. In Microparticulate Systems for the Delivery of Proteins and Vaccines; Cohen, S., Bernstein, H., Eds.; Marcel Dekker: New York, NY, USA, 1996; Volume 8, pp. 243-277.

79. Trubetskoy, V.S.; Torchilin, V.P. Use of polyoxyethylene-lipid conjugates as long-circulating carriers for delivery of therapeutic and diagnostic agents. Adv. Drug Deliv. Rev. 1995, 16, 311-320. [CrossRef]

80. Kwon, G.S.; Kataoka, K. Block-Copolymer Micelles as Long-Circulating Drug Vehicles. Adv. Drug Deliv. Rev. 1995, 16, 295-309. [CrossRef]

81. Kwon, G.S.; Okano, T. Soluble self-assembled block copolymers for drug delivery. Pharm. Res. 1999, 16, 597-560. [CrossRef] [PubMed]

82. Martin, A. Physical Pharmacy, 4th ed.; Williams and Wilkins: Baltimore, MA, USA, 1993; pp. 396-398.

83. Gao, Z.; Eisenberg, A. A model of micellization for block copolymers in solutions. Macromolecules 1993, 26, 7353-7360. [CrossRef]

84. Kakizawa, Y.; Kataoka, K. Block copolymer micelles for delivery of gene and related compounds. Adv. Drug Deliv. Rev. 2002, 54, 203-222. [CrossRef]

85. Torchilin, V.P. Structure and design of polymeric surfactant-based drug delivery systems. J. Control. Release 2001, 73, 137-172. [CrossRef]

86. Lin, S.Y.; Kawashima, Y. The influence of three poly(oxyethylene) poly(oxypropylene) surface-active block copolymers on the solubility behavior of indomethacin. Pharm. Acta Helv. 1985, 60, 339-344. [PubMed]

87. Lin, S.Y.; Kawashima, Y. Pluronic surfactants affecting diazepam solubility, compatibility and adsorption from i.v. admixture solutions. J. Pharm. Sci. Technol. 1985, 41, 83-87.

88. Yokoyama, M.; Okano, T.; Kataoka, K. Improved synthesis of adriamycin-conjugated poly(ethylene oxide)-poly(aspartic acid) block copolymer and formation of unimodal micellar structure with controlled amount of physically entrapped adriamycin. J. Control. Release 1994, 32, 269-277. [CrossRef]

89. Yokoyama, M.; Fukushima, S.; Uehara, R.; Okamoto, K.; Kataoka, K.; Sakurai, Y. Characterization of physical entrapment and chemical conjugation of adriamycin in polymeric micelles and their design for in vivo delivery to a solid tumor. J. Control. Release 1998, 50, 79-92. [CrossRef] 
90. Kabanov, A.V.; Chekhonin, V.P.; Alakhov, V.Y.; Batrakova, E.V.; Lebedev, A.S.; Melik-Nubarov, N.S. The neuroleptic activity of haloperidol increases after its solubilization in surfactant micelles. FEBS Lett. 1989, 258, 343-345. [CrossRef]

91. Hagan, S.A.; Coombes, A.G.A.; Garnett, M.C.; Dunn, S.E.; Davies, M.C.; Illum, L. Polylactide-poly(ethelene glycol) copolymers as drug delivery systems, 1 . Characterization of water dispersible micelle-forming systems. Langmuir 1996, 12, 2153-2161. [CrossRef]

92. Inoue, T.; Chen, G.; Nakamae, K.; Hoffman, A.S. An AB block copolymers of oligo(methyl methacrylate) and poly(acrylic acid) for micellar delivery of hydrophobic drugs. J. Control. Release 1998, 51, 221-229. [CrossRef]

93. Zeng, J.G.; Shi, K.Y.; Zhang, Y.Y.; Sun, X.H.; Zhang, B.L. Construction and micellization of a noncovalent double hydrophilic block copolymer. Chem. Commun. 2008, 32, 3753-3755. [CrossRef] [PubMed]

94. Zhao, C.W.; Zhuang, X.L.; He, C.L.; Chen, X.S.; Jing, X.B. Synthesis of Novel Thermo- and pH-Responsive Poly(L-lysine)-Based Copolymer and its Micellization in Water. Macromol. Rapid Commun. 2008, 29, 1810-1816. [CrossRef]

95. Gillies, E.R.; Jonsson, T.B.; Frechet, J.M.J. Stimuli-responsive supramolecular assemblies of linear-dendritic copolymers. J. Am. Chem. Soc. 2004, 126, 11936-11943. [CrossRef] [PubMed]

96. Washington, C. Drug release from microdisperse systems: A critical review. Int. J. Pharm. 2005, 58, 1-12. [CrossRef]

97. Hubbell, J.A. Materials science: Enhancing drug function. Science 2003, 300, 596-596. [CrossRef] [PubMed]

98. Jiang, X.; Lavender, C.A.; Woodcock, J.W.; Zhao, B. Multiple micellization and dissociation transitions of thermo- and light-sensitive poly(ethylene oxide)- $b$-poly(ethoxytri(ethylene glycol) acrylate-co-o-nitrobenzyl acrylate) in water. Macromolecules 2008, 41, 2632-2643. [CrossRef]

99. Kwon, G.S.; Naito, M.; Yokoyama, M.; Okano, T.; Sakurai, Y.; Kataoka, K. Block copolymer micelles for drug delivery: Loading and release of doxorubicin. J. Control. Release 1997, 48, 195-201. [CrossRef]

100. Harada, A.; Kataoka, K. Novel polyion complex micelles entrapping enzyme molecules in the core. Preparation of narrowly-distributed micelles from lysozyme and poly(ethylene glycol)-poly(aspartic acid) block copolymer in aqueous medium. Macromolecules 1998, 31, 288-294. [CrossRef]

101. Katayose, S.; Kataoka, K. Remarkable increase in nuclease resistance of plasmid DNA through supramolecular assembly with poly(ethylene glycol)-poly(L-lysine) block copolymer. J. Pharm. Sci. 1998, 87, 160-163. [CrossRef] [PubMed]

102. Kabanov, A.V.; Kabanov, V.A. Interpolyelectrolyte and block ionomer complexes for gene delivery: Physicochemical aspects. Adv. Drug Deliv. Rev. 1990, 30, 49-60. [CrossRef]

103. Batrakova, E.V.; Li, S.; Miller, D.W.; Kabanov, A.V. Pluronic P85 increases permeability of a broad spectrum of drugs in polarized BBMEC and Caco-2 cell monolayers. Pharm. Res. 1999, 16, 1366-1372. [CrossRef] [PubMed]

104. Kabanov, A.V.; Slepnev, V.I.; Kuznetsova, L.E.; Batrakova, E.V.; Alakhov, V.; Melik-Nubarov, N.S.; Sveshnikov, P.G.; Kabanov, V.A. Pluronic micelles as a tool for lowmolecular compound vector delivery into a cell: Effect of Staphylococcus aureus enterotoxin B on cell loading with micelle incorporated fluorescent dye. Biochem. Int. 1992, 26, 1035-1042. [PubMed]

105. Kabanov, A.V.; Alakhov, V.Y. Pluronic block copolymers in drug delivery: From micellar nanocontainers to biological response modifiers. Crit. Rev. Ther. Drug Carrier Syst. 2002, 19, 1-72. [CrossRef] [PubMed]

106. Batrakova, E.V.; Li, S.; Vinogradov, S.V.; Alakhov, V.Y.; Miller, D.W.; Kabanov, A.V. Mechanism of pluronic effect on P-glycoprotein efflux system in blood-brain barrier: Contributions of energy depletion and membrane fluidization. J. Pharmacol. Exp. Ther. 2001, 299, 483-493. [PubMed]

107. Kabanov, A.V.; Batrakova, E.V.; Miller, D.W. Pluronic block copolymers as modulators of drug efflux transporter activity in the blood-brain barrier. Adv. Drug Delivery Rev. 2003, 55, 151-164. [CrossRef]

108. Sahay, G.; Batrakova, E.V.; Kabanov, A.V. Different Internalization Pathways of Polymeric Micelles and Unimers and Their Effects on Vesicular Transport. Bioconj. Chem. 2008, 19, 2023-2029. [CrossRef] [PubMed]

109. Kabanov, A.V. Polymer genomics: An insight into pharmacology and toxicology of nanomedicines. Adv. Drug Deliv. Rev. 2006, 58, 1597-1621. [CrossRef] [PubMed]

110. Torchilin, V. Tumor delivery of macromolecular drugs based on the EPR effect. Adv. Drug Deliv. Rev. 2011, 63, 131-135. [CrossRef] [PubMed]

111. Meng, F.; Cheng, R.; Deng, C.; Zhong, Z. Intercellular drug release nanosystems. Mater. Today 2012, 15, 436-442. [CrossRef] 
112. Osada, K.; Christie, R.J.; Kataoka, K. Polymeric micelles from poly(ethylene glycol)-poly(amino acid) block copolymer for drug and gene delivery. J. R. Soc. Interface R. Soc. 2009, 6, S325-S339. [CrossRef] [PubMed]

113. Song, L.; Shen, Y.; Hou, J.; Lei, L.; Guo, S.; Qian, C. Polymeric micelles for parenteral delivery of curcumin: preparation, characterization and in vitro evaluation. Colloid Surf. A 2011, 390, 25-32. [CrossRef]

114. Song, Z.; Feng, R.; Sun, M.; Guo, C.; Gao, Y.; Li, L.; Zhai, G. Curcumin-loaded PLGA-PEG-PLGA triblock copolymeric micelles: Preparation, pharmacokinetics and distribution in vivo. J. Colloid Interface Sci. 2011, 354, 116-123. [CrossRef] [PubMed]

115. Zhao, L.; Du, J.; Duan, Y.; Zang, Y.; Zhang, H.; Yang, C.; Cao, F.; Zhai, G. Curcumin loaded mixed micelles composed of pluronic P123 and F68: Preparation, optimization and in vitro characterization. Colloid Surf. B 2012, 97, 101-108. [CrossRef] [PubMed]

116. Samanta, S.; Roccatano, D. Interaction of curcumin with PEO-PPO-PEO triblock copolymers: A molecular dynamics study. J. Phys. Chem. B 2013, 117, 3250-3257. [CrossRef] [PubMed]

117. Gong, C.; Deng, S.; Wu, Q.; Xiang, M.; Wei, X.; Li, L.; Gao, X.; Wang, B.; Sun, L.; Chen, Y.; et al. Improving antiangiogenesis and anti-tumor activity of curcumin by biodegradable polymeric micelles. Biomaterials 2013, 34, 1413-1432. [CrossRef] [PubMed]

118. Liu, L.; Sun, L.; Wu, Q.; Guo, W.; Li, L.; Chen, Y.; Li, Y.; Gong, C.; Qian, Z.; Wei, Y. Curcumin loaded polymeric micelles inhibit breast tumor growth and spontaneous pulmonary metastasis. Int. J. Pharm. 2013, 443, 175-182. [CrossRef] [PubMed]

119. Ma, Z.; Haddadi, A.; Molavi, O.; Lavasanifar, A.; Lai, R.; Samuel, J. Micelles of poly(ethylene oxide)- $b$-poly( $\varepsilon$-caprolactone) as vehicles for the solubilization, stabilization, and controlled delivery of curcumin. J. Biomed. Mater. Res. A 2008, 86, 300-310. [CrossRef] [PubMed]

120. Soliman, G.M.; Sharma, A.; Cui, Y.; Sharma, R.; Kakkar, A.; Maysinger, D. Miktoarm Star Micelles Containing Curcumin Reduce Cell Viability of Sensitized Glioblastoma. J. Nanomed. Biother. Discov. 2014, 4, 124. [CrossRef]

121. Yang, X.; Li, Z.; Wang, N.; Li, L.; Song, L.; He, T.; Sun, L.; Wang, Z.; Wu, Q.; Luo, N.; et al. Curcumin-Encapsulated Polymeric Micelles Suppress the Development of Colon Cancer in vitro and in vivo. Sci. Rep. 2015, 5, 10322. [CrossRef] [PubMed]

122. Kohut, A.; Voronov, A. Hierarchical Micellar Structures from Amphiphilic Invertible Polyesters: ${ }^{1} \mathrm{H}$ NMR Spectroscopic Study. Langmuir 2009, 25, 4356-4360. [CrossRef] [PubMed]

123. Hevus, I.; Kohut, A.; Voronov, A. Interfacial micellar phase transfer using amphiphilic invertible polymers. Pol. Chem. 2011, 2, 2767-2770. [CrossRef]

124. Hevus, I.; Modgil, A.; Daniels, J.; Kohut, A.; Sun, C.; Stafslien, S.; Voronov, A. Invertible Micellar Polymer Assemblies for Delivery of Poorly Water-Soluble Drugs. Biomacromolecules 2012, 13, 2537-2545. [CrossRef] [PubMed]

125. Kudina, O.; Kohut, A.; Tarnavchyk, I.; Hevus, I.; Voronov, A. Solvent-Responsive Self-Assembly of Amphiphilic Invertible Polymers Determined with SANS. Langmuir 2014, 30, 3310-3318. [CrossRef] [PubMed]

126. Kudina, O.; Shogren, K.L.; Gustafson, K.T.; Yaszemski, M.J.; Maran, A.; Voronov, A. Invertible micellar polymer nanoassemblies target bone tumor cells but not normal osteoblast cells. Future Sci. OA 2015, 1, 1-9. [CrossRef]

127. Kohut, A.; Hevus, I.; Voronov, S.; Voronov, A. Invertible Polymers and their Applications. In Industrial Applications for Intelligent Polymers and Coatings; Hosseini, M., Makhlouf, A.S.H., Eds.; Springer International Publishing: Cham, Switzerland, 2016; pp. 399-416.

128. Kohut, A.; Sieburg, L.; Vasylyev, S.; Kudina, O.; Hevus, I.; Stafslien, S.; Daniels, J.; Kislenko, V.; Voronov, A. Amphiphilic invertible polymers (AIPs): Micellization and self-assembly in aqueous solutions. In Amphiphiles: Molecular Assembly and Applications; Nagarajan, R., Ed.; Oxford University Press Inc.: Washington, DC, USA, 2011; pp. 205-224.

(C) 2016 by the authors; licensee MDPI, Basel, Switzerland. This article is an open access article distributed under the terms and conditions of the Creative Commons Attribution (CC-BY) license (http:/ / creativecommons.org/licenses/by/4.0/). 